\title{
Changes in dental practice in times of COVID-19: review and recommendations for dental health care
}

\section{Mudanças na prática odontológica em tempos de COVID-19: revisão e recomendações para o cuidado odontológico}

\author{
Manuela Gonçalves de Souza e Silva SILVEIRA ${ }^{1}$ iD https://orcid.org/0000-0002-3924-8121 \\ Matheus dos Santos FERNANDEZ1 ${ }^{1}$ iD https://orcid.org/0000-0001-7781-3083 \\ Thais Freitas Formozo TILLMANN ${ }^{1}$ iD https://orcid.org/0000-0002-2386-0826 \\ Júlia Freire DANIGNO² iD https://orcid.org/0000-0001-9919-8608 \\ Mariana Silveira ECHEVERRIA ${ }^{1}$ iD http://orcid.org/0000-0002-2045-4232 \\ Alexandre Emidio Ribeiro SILVA' 1 iD https://orcid.org/0000-0001-6402-0789
}

\begin{abstract}
The aim of this article was to discuss biosafety measures described in the main protocols for minimizing the risk of COVID-19 transmission during dental care. COVID-19 appeared in China in late 2019 and quickly spread to other countries. Factors inherent to dental practice, such as proximity to the patient, transmission through saliva and breath, and the generation of aerosols during procedures, place the dental team at the top of the list among the most vulnerable healthcare providers. Health authorities initially recommended only maintaining urgent and emergency care and suspending elective dental procedures. Currently, elective care is gradually being resumed and requires numerous adjustments to the environment and professional routine in terms of biosafety. Several methods had been recommended to prevent the spread of other infectious diseases prior to the outbreak of COVID-19. However, further modifications are needed for the waiting room, patient screening and flow, procedures, garments, and even in dental office itself. Thus, dental professionals need to be prepared to adopt the new recommendations in order to reduce the chance of disease transmission.
\end{abstract}

Indexing terms: Dentistry; Biosafety; Coronavirus Infections.

\section{RESUMO}

O objetivo deste artigo foi descrever as medidas de biossegurança presentes nos principais protocolos para diminuir os riscos de transmissão de COVID-19 durante os atendimentos odontológicos. O COVID-19 surgiu na China no final de 2019 e se espalhou rapidamente por outros países. Fatores da prática odontológica, como a proximidade com o paciente, contato com a saliva e respiração, bem como a geração de aerossóis em diversos procedimentos, colocam a equipe odontológica no topo da lista entre os profissionais com maior risco para o COVID-19. Inicialmente, as autoridades de saúde recomendaram apenas a manutenção dos atendimentos de

\footnotetext{
$\boldsymbol{\nabla V} \boldsymbol{\nabla}$
}

1 Universidade Federal de Pelotas, Faculdade de Odontologia, Departamento de Odontologia Social e Preventiva. Rua Gonçalves Chaves, 457, sala 512, Centro, Pelotas, RS, Brasil. Correspondence to: ERA SILVA. E-mail: <aemidiosilva@gmail.com>.

2 Universidade Federal do Rio Grande, Faculdade de Medicina. Rio Grande, RS, Brasil.

$\checkmark \nabla v$

How to cite this article

Silveira MGSSS, Fernandez MS, Tillmann TFF, Danigno JF, Echeverria MS, Silva AER. Changes in dental practice in times of COVID-19: review and recommendations for dental health care. RGO, Rev Gaúch Odontol. 2021;69:e2021001. http://dx.doi.org/10.1590/198186372021000120200073 
urgência e emergência, suspendendo os procedimentos eletivos. Atualmente, a retomada dos atendimentos eletivos vem ocorrendo em vários países de forma gradual e exige inúmeras adequações nos ambientes e na rotina profissional em termos de biossegurança. Diversas condutas já eram preconizadas pelas autoridades sanitárias na prevenção da disseminação de outras doenças infecciosas antes do COVID-19. No entanto, são necessárias novas modificações na sala de espera, triagem e fluxo de pacientes, paramentação e até no próprio consultório odontológico. Dessa forma, os profissionais de odontologia devem estar preparados para adotar as novas recomendações e diminuir a chance de transmissão da doença.

Termos de indexação: Odontologia; Biossegurança; infecções por Coronavirus.

\section{INTRODUCTION}

In December of 2019, cases of diseases that caused severe pneumonia were reported for the first time in Wuhan, capital of Hubei, China [1]. This was followed by an exponential increase in the number of cases throughout the world [2]. The causal agent of the disease was confirmed to be the novel coronavirus (CoV). In March of 2020, the World Health Organization (WHO) [3] declared the emergence of a pandemic caused by a new strain of the virus, denominated severe acute respiratory syndrome by coronavirus 2 (SARS CoV-2) [4]. This pandemic became known as the disease caused by the novel coronavirus COVID-19.

Previous outbreaks of severe acute respiratory syndrome by coronavirus (SARS-CoV) emerged in China and resulted in hundreds of deaths in 37 countries between 2002 and 2003 [5]. However, SARS CoV-2 seems to be more infectious and lethal compared to SARS-CoV [6]. Vaccines for SARS COV-2 are rapidly being developed but will probably not be available in time to assist in combating this first wave of the pandemic [7].

COVID-19 is changing the routine of healthcare services. It has become necessary to adapt to a new work method, as healthcare providers run a greater risk of infection [8]. The possible transmission through saliva and the generation of airborne particles in dental offices place the dental team among the healthcare providers with greater vulnerability to infection in the workplace [9].

At the outset of COVID-19, national and international healthcare institutions and organizations recommended the suspension of elective dental procedures and the maintenance of only cases of urgent and emergency care $[10,11]$. However, considering the long duration of the pandemic and the fact that other demands for dental treatment continue to emerge and accumulate, elective procedures have gradually been resumed $[12,13]$.

In this context, numerous questions arise regarding the need to alter current biosafety norms by dental professionals during and after the pandemic due to the characteristics and transmission modes of COVID-19 $[9,14]$. Thus, the aim of this article is to present adequate biosafety measures based on the main national and international scientific papers, manuals, and guidelines published in the literature to date that should be adopted in routine daily practice to minimize the risks of COVID-19 transmission during dental appointments for both patient and the dental team.

\section{DISCUSSION}

\section{Severe acute respiratory syndrome by coronavirus 2 (SARS-COV-2)}

The novel coronavirus is the pathological agent responsible for causing the 2019 coronavirus disease (COVID-19), which is a type of upper respiratory infection with the potential for the development of infectious pneumonia in humans $[3,15]$. The causal agent of the pandemic outbreak of COVID-19 is genetically characterized as a member of the family Coronaviridae of enveloped viruses with a single-stranded, positive-sense RNA genome [16]. Based on the genome sequencing of the virus and the analysis of its evolution, bats are suspected to be the natural host of origin of the virus and SARS-CoV-2 may be transmitted from bats through unknown intermediate hosts capable of infecting humans $[1,17]$.

The main modes of dissemination of the virus among humans are respiratory droplets (aerosols), bodily fluids, direct oral contact, and transmission through contaminated environmental surfaces [18]. Current evidence sustains the absence of vertical transmission of the disease [19]. However, there is the possibility of fecal transmission [20].

The symptoms of infection by COVID-19 appear after an incubation period of approximately 5.2 days (range: one to 14 days) $[15,21]$. Recent clinical studies demonstrate that many individuals who test positive may 
not exhibit any symptoms at all or may present a mild, self-limiting viral syndrome consisting of fever, malaise, dry cough, and shortness of breath [22]. However, less common symptoms have been reported, such as diarrhea, nausea, vomiting, abdominal discomfort, phlegm production, and lymphopenia, varying significantly among different population groups, along with early-onset and mild symptoms of the disease often accompanied by typical respiratory alterations [23]. Some individuals develop a secondary syndrome, including viral pneumonia, oxygen insufficiency, and acute respiratory distress, which requires mechanical ventilation and hospitalization in complex treatment units, where the aggravation of the infection can, in some cases, lead to death attributable to COVID-19 [24].

According to the US Centers for Disease Control and Prevention (CDC), individuals aged 65 years or older are at greater risk of developing the severe form of the disease, especially those who live in retirement homes or long-term care institutions. Individuals of any age with other health problems, such as chronic lung disease, moderate to severe asthma, severe heart disease, a compromised immune system, severe obesity, diabetes, chronic kidney disease, and liver disease, are also at risk of developing the severe form of the disease [25].

Although COVID-19 has been reported in individuals of different age groups, patients with an advanced age seem to be more susceptible to the infection [26], whereas children and adolescents seem to be affected less frequently than adults $[27,28]$. The reasons suggested for this regard the fact that youths have a more active innate immune response, healthier lungs, and fewer underlying disorders [27]. Moreover, the frequency of asymptomatic clinical cases is quite high among children and adolescents [22, 28].

Despite global efforts to impede the propagation of the virus since the first case of infection reported in China at the end of 2019, COVID-19 spread rapidly among the continents $[29,30]$. By the first half of May 2020, the WHO had registered more than 200 countries affected by the virus, with more than four million confirmed cases and more than 280 thousand deaths [31]. Europe concentrates the largest number of confirmed cases, followed by the Americas and the Eastern Mediterranean [31].

\section{Risks to healthcare providers}

Healthcare providers are exposed to risks on a daily basis that make them vulnerable to infection by the novel coronavirus [32]. According to the WHO, such risks include exposure to pathogens, long working hours, psychological suffering, fatigue, professional burnout, stigmas, as well as physical and psychological violence [33].

A healthy, well-equipped workforce is essential to managing cases of COVID-19 effectively. Unfortunately, however, the infection of healthcare providers is a common occurrence, especially among those on the front lines. A study addressing the clinical characteristics of 138 patients hospitalized due to COVID-19 in Wuhan, China, showed that $29 \%$ were healthcare providers [22]. Considering the incubation period and the possibility of transmission by asymptomatic infected individuals, all patients should be managed as potential transmitters and healthcare providers who maintain close contact with patients and work colleagues should be considered potentially infected $[32,33]$.

\section{Risks to dental staff}

Due to the characteristics of dental practice (close proximity to the patient and direct contact with oral fluids), dentists and dental staff are particularly vulnerable to infection by COVID-19 [13,14].

SARS-CoV-2 has been found in the saliva of infected patients and positive viral cultures indicate that saliva contains living viruses capable of transmission [34]. Thus, special care is required during dental appointments, followed by the disinfection of all instruments, equipment, and materials [14]. The important aspects that cause concern are the contact with saliva and the fact that many dental procedures involve the use of high-speed handpieces, ultrasound devices, and the air-water syringe, which generate airborne particles that can disseminate the secretions of patients in the form of aerosols [35]. The particles generated are so small that they can remain in the air for a long period before settling, causing concern with regards to the contamination of surfaces (walls, floors, and furniture) as well as the inhalation of contaminated particles [36]. A recent study showed that SARS-CoV-2 remained viable and infectious in experimentally produced aerosols, with a slight reduction in infection potential only after three hours of observation [37].

Current protection measures used in daily clinical practice seem not to be effective at impeding the propagation of COVID-19 in offices, clinics, and hospitals 
that offer dental care, requiring the urgent adherence to stricter infection control protocols [14].

\section{Necessary biosafety measures in dental care due to the covid-19 pandemic}

Recommendations and guidelines for dental care in the context of the current pandemic have been formulated by international organizations [38, 39] and national institutions $[40,41]$. The aim of these publications is to guide dental staff regarding the adoption of prevention and infection control measures to avoid or minimize the transmission of microorganisms during dental care in the current COVID-19 scenario.

However, the concern with biosafety in dental care was a widely discussed issue even prior to the COVID-19 pandemic. In 2003, the CDC published guidelines for infection control in dental care, with an updated document published in 2016 [42,43]. In 2014, the WHO published general recommendations regarding infection control measures in healthcare for cases of patients with acute respiratory disease following the influenza $A$ ( $H 1 N 1$ virus) pandemic [44].

It is therefore extremely important to have knowledge on the main national and international recommendations and guidelines that have been proposed for dental care after the WHO declared COVID-19 to be a pandemic.

\section{Waiting room}

The waiting room is the place where patients have their first contact with the clinic, dental staff, and other patients. It is therefore necessary to organize this environment to reduce the chances of SARS-CoV-2 transmission.

The current recommendations regarding the organization of the waiting room alter norms prior to the COVID-19 pandemic. Some measures were established by the WHO and CDC after the outbreak of the Influenza A pandemic, such as natural ventilation, the size of the room, the minimum distance between chairs, availability of surgical masks for patients with respiratory symptoms, dispensers with hand sanitizer containing $70 \%$ alcohol gel, the offer of tissues for respiratory hygiene, and the display of informative posters $[43,44]$. The WHO manual also mentions the possibility of using a room to accommodate a patient that has an acute respiratory illness, whenever possible. However, the orientation regarding an antibacterial floor mat, the disinfection of possessions, the restriction of accompaniers, and the organization of the schedule in such a way as to space appointments between one patient and another to minimize contact between individuals emerged as new recommendations due to the SARS-CoV-2 pandemic. The main recommendations for the waiting room are listed in table 1.

Table 1. Norms necessary for dental care during COVID-19 pandemic according to national and international recommendations. Brazil. 2020

\section{WAITING ROOM}

I. Install an antibacterial floor mat at the entrance of the dental office $[38,40,41]$.

II. Area of waiting room should be $1.2 \mathrm{~m}^{2}$ per person $[38,40,41]$.

III. Minimum distance of $1 \mathrm{~m}$ between seats [38,40,41].

IV. Display visual warnings (e.g., posters, flyers, and signs) at the entrance of the dental clinic and strategic places (e.g., waiting areas, parking lot, and elevators) providing patients and accompaniers/visitors with instructions on how to sanitize the hands, respiratory etiquette (covering the mouth and nose with the forearm, inner portion of the elbow, or tissue to cough or sneeze), and social distancing [38,40,41].

V. Make available disposable tissues for respiratory hygiene. There should also be a trash bin with a foot pedal for the subsequent disposal of the used tissue $[38,40,41]$.

VI. Dispensers with $70 \%$ alcohol solution or gel for sanitizing hands accessible to patients $[38,40,41]$.

VII. Lavatory available with sink to wash face and hands, dispenser with liquid soap, paper towel holder, and trash bin with lid and opening without hand contact $[38,40,41]$

VIII. Make available surgical masks in cases of need for covering nose and mouth with easy access to patients. Instructions for use should also be offered $[38,40,41]$.

IX. Disinfect purses/bags that enter the clinic with $70 \%$ alcohol spray; other possessions should be stored in lockers. Whenever there is a need to handle these objects, hand washing is necessary $[38,40,41]$.

X. Maintain environment ventilated $[38,40,41]$.

XI. Remover, restrict, or control the use of objects shared by patients (e.g., pens, clipboards, telephones, and magazines) [38,40,41].

XII. Space appointments sufficiently to avoid or minimize contact between patients in the waiting room [38,40,41].

XIII. Greatly restrict the presence of accompaniers in the examining room. Only permit accompaniers to remain in specific cases, such as during procedures for pediatric patients, persons with special needs, and older people [38,40,41]. 
Table 1. Norms necessary for dental care during COVID-19 pandemic according to national and international recommendations. Brazil. 2020.

\section{WAITING ROOM}

XIV. Whenever possible, make available a comfortable reserved room for patients with possible infection to remain when waiting for an appointment. This room should also be used as a post-treatment recovery room in cases of need. If such a space does not exist, a chair should be available in the waiting room with a distance of 1 to $2 \mathrm{~m}$ from the other chairs [38,40,41].

\section{SCREENING}

I. Ensure that all patients are asked about symptoms of a respiratory infection or contact with possible patients with the novel coronavirus [41].

II. When scheduling appointments, ask whether the patient has symptoms of respiratory infection (e.g., cough, coryza, difficulty breathing). Such patients should be instructed to postpone the appointment until the symptoms improve, if possible [41].

III. Counsel patients to adopt appropriate preventive measures if presenting symptoms (e.g., using a surgical mask upon entering the service, adopting respiratory etiquette, and washing the hands) $[40,41]$.

IV. If a patient requires an accompanier, this individual should also be screened for COVID-19 [40,41].

V. Elective procedures (those not clinically classified as urgent) should be postponed [40].

VI. The attendant should measure the body temperature of patients that enter the clinic with an infrared digital thermometer and update the patient history (even for patients on return visits, always ask about viral symptoms or whether some family member, friend, or acquaintance had or has any symptoms). If a patient has a temperature higher than $37^{\circ} \mathrm{C}$, he/she should be provided a mask, informed about the symptoms, and asked to return home to rest and seek medical care $[38,41]$.

\section{DISINFECTION OF CLINICAL ENVIRONMENT}

\section{Physical space}

I. Cleaning of the dental chair and stool, spit sink, hoses, electrical cords, and other peripheral equipment handled by the dentist and/or assistance should be performed with water and neutral soap and disinfection should be performed with $1 \%$ sodium hypochlorite, quaternary ammonia, and biguanide, glucoprotamin, or $70 \%$ alcohol. In the presence of organic matter, apply $1 \%$ sodium hypochlorite to organic matter and await five minutes to remove, then perform cleaning with soap and water [45].

II. Cleaning and disinfection should begin from the least contaminated to the most contaminated location. Next, walls and floors should be cleaned in a single direction using a cloth or sponge and then dried with clean cloths [45].

III. For cleaning of biofilm from air and water hoses, use $0.2 \%$ peracetic acid for high-level disinfection [39].

IV. It is necessary to ensure the cleaning of objects that have had contact with individuals with acute respiratory illnesses, such as handpieces, which should be disinfected with an alcohol-based solution [44].

$\mathrm{V}$. The promotion of ventilation in the environment should be constant and waste management should be performed in accordance with state and federal protocols [39].

\section{Dental instruments}

I. All handpieces (high and low speed) should undergo a decontamination process with enzymatic detergent, cleaning, and sterilization [39].

II. Instruments need to be previously wet and cleaned with enzymatic detergent (see manufacturer's instructions). Dental materials to be disinfected should be immersed in enzymatic detergent for five minutes in a plastic recipient or ultrasound cube. Next, the cleaning step should be performed until all residue is removed from the instruments. Drying should be performed with paper towel or sterile surgical compresses and the material should be wrapped for subsequent sterilization [45].

III. Sterilization of objects by physical means should be performed with the use of moist heat (autoclave), following the manufacturer's instructions, whose equipment should be registered with the Health Ministry, or the use of dry heat (oven) at $170^{\circ} \mathrm{C}$ for two hours [45].

\section{CLINICAL CARE}

I. Pre-procedure mouth rinsing with 0.5 or $1 \%$ hydrogen peroxide or $0.2 \%$ aqueous solution of povidone-iodine. Due to the sensitivity of the virus to oxidation, this procedure can reduce the viral load in the patient's saliva $[40,41]$.

II. Extraoral radiographs should be considered alternatives to intraoral radiographs, which should be avoided due to the stimulation of the secretion of saliva and coughing $[38,40,41]$.

III. Control the production of aerosols. Manual instruments should be prioritized. High-speed handpieces, ultrasound devices, and the air-water syringe should be avoided as far as possible $[38,40,41]$.

IV. Whenever possible, use absolute isolation with a rubber dam to reduce the dispersion of droplets and aerosols $[38,40,41]$.

V. Care should be performed with four hands for better infection control $[38,40,41]$.

VI. Use high-power suction pump to reduce the quantity of saliva in the oral cavity and minimize the cough stimulus $[38,40,41]$.

VII. Preferably use resorbable suture thread, eliminating the need for a return appointment for removal $[38,40,41]$.

VIII. When pharmacological pain management is necessary, ibuprofen should be avoided [47]. 


\section{Screening for risk}

Screening for the identification of patients with a risk of infection by COVID-19 is a prevention measure for the transmission of the disease, especially in the dental setting, which is considered to pose a high risk for contagion. With the H1N1 pandemic, the $\mathrm{WHO}$ and $\mathrm{CDC}$ recommended screening for the risk of respiratory infections. The WHO states that healthcare providers should perform screening for acute respiratory illnesses. When such a case is detected, healthcare providers should furnish pertinent information and instructions to the patient and, in cases of public interest, the health authorities should be notified [44]. The CDC manual states that the health team should develop and execute a system for the detection and early treatment of potentially infected individuals in the entrance area of the clinic or office and, when a patient is ill, non-urgent care should be rescheduled, whenever possible [43]. The main recommendations are listed in table 1.

\section{Dental care}

Some measures adopted during the clinical management of patients are of extreme importance to reducing the transmission of SARS-CoV-2 in the dental setting. Most current recommendations had previously been indicated as procedures that should be adopted to diminish the risk of the airborne transmission of microorganisms. The main measures are listed in table 1.

\section{Individual protective equipment}

During the COVID-19 pandemic, individual protective equipment (IPE) has become important, but also scarce in some countries, which has concerned international health authorities. For dental staff, some items that were previously recommended are currently considered mandatory. The upcoming sections describe IPE recommendations for dentists and the entire dental staff.

\section{Dentists}

According to manuals on dental care in the scenario of the COVID-19 pandemic, dentists should use an impermeable white coat/smock, head cover, gloves, surgical mask, and surface protection, which should be used during appointments and discarded after the appointment in the infected material bin. This IPE should be used during direct contact with the patient (physical examination) and removed during the administrative aspect of the appointment (e.g., writing with a pen or computer). Smocks should close from behind. Eyewear and face shields should be worn during appointments involving individuals with flu symptoms in the office. This equipment can be disinfected after each appointment and reused $[39,40]$.

Another change was the recommendation for the use of a particulate respirator (N95, PFF2, or similar type of mask). In procedures that generate aerosols (manipulation of airways, invasive exams), the mask should be exchanged after each appointment $[39,40]$. The WHO recommendations regarding infection control measures during health care for patients with respiratory illnesses previously established the use of particulate respirators when treating patients with any infection transmitted through the air or whenever performing hospital procedures that generate aerosols with the risk of the transmission of a pathogen. Although several aerosolgenerating procedures are performed in dentistry, the use of respirators was not applied to dental practice prior to the pandemic.

\section{Dental staff}

The dental staff may be composed of a secretary/ attendant, assistants, oral health technician, maintenance workers, security officer, etc. The different functions of the support team are extremely important to the maintenance of the clinical space and these staff members may be engaged directly or indirectly in dental procedures. Thus, the adoption of biosafety measures by each member of the team is fundamental and these measures are organized according to the degree of contact with patients.

Dental assistants and oral health technicians (hygienists) offer support to the dentist and are often within one meter of patients. Thus, they should use protective eyewear, a surgical mask, smock, latex gloves, and disposable cap. This equipment should be exchanged after each appointment, with the exception of the eyewear, which can be disinfected with an alcohol-based solution [40].

Staff members responsible for the reception and security who routinely come into contact less than one 
meter from patients should mandatorily wear surgical masks [40].

Cleaning staff, who come into contact with critical areas of contamination, should use a cap, protective eyewear or a face shield, surgical mask, smock, rubber gloves, and high rubber boots [40].

Besides IPE, the support staff should be instructed to inform patients and accompaniers to report any symptoms of respiratory infection (e.g., coughing, coryza, fever, difficulty breathing) upon arriving at the office and take the appropriate preventive actions, such as using a surgical mask upon entering the service $[39,40]$.

Prior to the COVID-19 pandemic, the recommendation was that all staff members who worked at healthcare services and dealt directly with patients with respiratory illnesses should wear masks [44]. The guidelines do not mention other necessary individual protective equipment. Furthermore, healthcare providers should develop and execute forms of detection and early referral of potentially infectious patients at the entranceway of the dental office. This includes rescheduling non-urgent care whenever possible [43].

\section{Disinfection of clinical environment and me- chanical barriers}

The disinfection of the clinical environment and the use of mechanical barriers are important prevention and infection control measures that should be implemented to avoid the transmission of microorganisms during dental care in the scenario of the COVID-19 pandemic. The main recommendations are described below.

\section{Disinfection of clinical environment}

\section{Physical space}

The physical space of the dental office as well as the main and peripheral dental equipment are subject to contamination by pathogenic microorganisms from the oral cavity of patients through direct contact, the touch of the gloved hands of the dental staff, drops of blood or saliva, and aerosols, which are deposited on these objects [40]. There have generally been no changes among the global recommendations regarding the cleaning and disinfection of the clinical space. The measures that should be executed in the dental setting are listed in table 1.

\section{Dental instruments}

Care procedures for dental instruments are the same as those prior to the COVID-19 pandemic. For instance, despite being considered semi-critical objects, handpieces can accumulate organic matter in the inner portion of the device [45]. If these devices are not adequately cleaned and heat sterilized, the next patient will be exposed to potentially infectious materials [43]. Metallic objects should generally be sterilized by a physical process. Chemical sterilization should only be employed for thermosensitive objects when there is no alternative method. In such cases, high-level chemical agents, such as peracetic acid, are a good option [45]. The main recommendations are listed in table 1.

\section{Physical barriers}

The following sites should have mechanical barriers (polyvinyl chloride [PVC] film or plastic bags): switches, reflector straps, headrests, arms of the dental chair, stool pad, body of air-water syringe, and tips of suction pump $[44,45]$.

Surfaces, such as countertops and auxiliary cart, such be covered with disposable, waterproof fabrics. Airwater syringes should have disposable tips [44].

The recommendations for the use of mechanical barriers prior to COVID-19 are the same and these barriers should be replaced after each patient $[43,45]$.

\section{CONCLUSION}

Dentists and staff are exposed to pathogens in daily dental practice through gingival fluids, saliva, and blood by either direct contact or in the form of aerosols. The COVID-19 pandemic has made the reorganization of the work environment necessary to minimize the risks of transmission.

National and international recommendations and guidelines existed prior to the outbreak of COVID-19 to prepare dental staff for the different biological risks inherent to the profession. Regarding the prevention of 
COVID-19, previously published protection measures, which were often neglected by the dental team, are not effective at impeding the transmission of the disease.

Beyond a mere increase in personal protection with IPE, changes are needed to the waiting room, patient screening, and the form of providing care - in other words, the entire dental care process. The aim of such changes is the non-propagation of SARS-CoV2 and any other pathogens. Therefore, following existing protocols is extremely important during every dental appointment.

All sectors of society need to be reorganized in this battle against the current COVID-19 pandemic, including dental services. From this moment onward, dentists need to adapt their working hours, reorganize the office, and hire a support team, which not only changes the form of offering care, but also has economic consequences. It is necessary to adapt to the new forms of prevention with the only certainty that nothing will be as it was before.

\section{Collaborators}

AER SILVA, MGSS SILVEIRA, MS FERNANDEZ, TFF TILLMANN, JF DANIGNO, MS ECHEVERRIA contributed to the conception, writing of the manuscript, critical review of the article, and approval of the final version.

\section{REFERENCES}

1. Lu H, Stratton CW, Tang YW. Outbreak of pneumonia of unknown etiology in Wuhan, China: The mystery and the miracle. J Med Virol. 2020 Apr;92(4):401-402. http://dx.doi. org/10.1002/jmv.25678

2. World Health Organization. Coronavirus Disease (COVID-19) Pandemic. 2020 [cited 2020 May 6]. Available from: <https:// covid19.who.int/s.

3. Sohrabi C, Alsafi Z, O'Neill N, Khan M, Kerwan A, Al-Jabir A, losifidis C, Agha R. World Health Organization declares global emergency: A review of the 2019 novel coronavirus (COVID-19). Int J Surg. 2020 Apr;76:71-76. http://dx.doi. org/10.1016/j.ijsu.2020.02.034

4. Lu R, Zhao X, Li J, Niu P, Yang B, Wu H, et al. Genomic characterisation and epidemiology of 2019 novel coronavirus: implications for virus origins and receptor binding. Lancet. 2020 Feb 22;395(10224):565-574. http://dx.doi.org/10.1016/ S0140-6736(20)30251-8

5. Peiris JS, Guan Y, Yuen KY. Severe acute respiratory syndrome. Nat Med. 2004 Dec;10(12 Suppl):S88-97. http://dx.doi. org/10.1038/nm1143

6. da Costa VG, Moreli ML, Saivish MV. The emergence of SARS, MERS and novel SARS-2 coronaviruses in the 21st century. Arch Virol. 2020 Jul;165(7):1517-1526. http://dx.doi. org/10.1007/s00705-020-04628-0

7. Amanat F, Krammer F. SARS-CoV-2 Vaccines: Status Report. Immunity. 2020 Apr 14;52(4):583-589. http://dx.doi.org/10. 1016/j.immuni.2020.03.007

8. Meng L, Hua F, Bian Z. Coronavirus Disease 2019 (COVID-19): Emerging and Future Challenges for Dental and Oral Medicine. J Dent Res. 2020 May;99(5):481-487. http://dx.doi. org/10.1177/0022034520914246

9. Sabino-Silva R, Jardim ACG, Siqueira WL. Coronavirus COVID-19 impacts to dentistry and potential salivary diagnosis. Clin Oral Investig. 2020 Apr;24(4):1619-1621. http://dx.doi.org/10.1007/s00784-020-03248-x

10. Centers of Disease Control and Prevention. Dental Settings. 2020[cited 2020 May 6]. Available from: <https://www.cdc. gov/coronavirus/2019-ncov/hcp/dental-settings.html>.

11. Brasil. Ministério da Saúde. Nota técnica no 9/2020 - CGSB. Atendimento odontológico no SUS durante a epidemia do novo coronavírus [Acesso em 6 maio 2020]. Disponível em: <http://189.28.128.100/dab/docs/portaldab/documentos/ COVID_19_ATENDIMENTO\%20ODONTOLOGICO_SUS_ APS_20200319_ver001.pdf>.

12. Guo H, Zhou Y, Liu X, Tan J. The impact of the COVID-19 epidemic on the utilization of emergency dental services. J Dent Sci. 2020 Mar 16. http://dx.doi.org/10.1016/j. jds.2020.02.002

13. Alharbi A, Alharbi S, Alqaidi S. Guidelines for dental care provision during the COVID-19 pandemic. Saudi Dent J. 2020 May;32(4):181-186. http://dx.doi.org/10.1016/j.sdentj. 2020.04.001

14. Lo Giudice R. The Severe Acute Respiratory Syndrome Coronavirus-2 (SARS CoV-2) in Dentistry. Management of Biological Risk in Dental Practice. Int J Environ Res Public Health. 2020 Apr 28;17(9):3067. http://dx.doi.org/10.3390/ ijerph17093067

15. Nicola M, O'Neill N, Sohrabi C, Khan M, Agha M, Agha R. Evidence based management guideline for the COVID-19 pandemic - Review article. Int J Surg. 2020 May;77:206-216. http://dx.doi.org/10.1016/j.ijsu.2020.04.001

16. Rothan HA, Byrareddy SN. The epidemiology and pathogenesis of coronavirus disease (COVID-19) outbreak. J Autoimmun. 2020 May; 109:102433. http://dx.doi.org/10.1016/j.jaut. 2020.102433

17. Zhou P, Yang XL, Wang XG, Hu B, Zhang L, Zhang $W$ et al. A pneumonia outbreak associated with a new coronavirus of probable bat origin. Nature. 2020 Mar; 579(7798):270-273. http://dx.doi.org/10.1038/s41586-020-2012-7

18. Ong SWX, Tan YK, Chia PY, Lee TH, Ng OT, Wong MSY, et al. Air, Surface Environmental, and Personal Protective Equipment Contamination by Severe Acute Respiratory Syndrome Coronavirus 2 (SARS-CoV-2) From a Symptomatic Patient. JAMA. 2020 Apr 28;323(16):1610-1612. http:// dx.doi.org/10.1001/jama.2020.3227

19. Chen H, Guo J, Wang C, Luo F, Yu X, Zhang W, et al. Clinical characteristics and intrauterine vertical transmission potential of COVID-19 infection in nine pregnant women: 
a retrospective review of medical records. Lancet. 2020 Mar 7;395(10226):809-815. http://dx.doi.org/10.1016/S0140-67 36(20)30360-3

20. Amirian ES. Potential fecal transmission of SARS-CoV-2: Current evidence and implications for public health. Int J Infect Dis. 2020 Jun;95:363-370. http://dx.doi.org/10.1016/j. ijid.2020.04.057

21. Bai $Y$, Yao L, Wei T, Tian F, Jin DY, Chen L, et al. Presumed Asymptomatic Carrier Transmission of COVID-19. JAMA. 2020 Apr 14;323(14):1406-1407. http://dx.doi.org/10.1001/ jama.2020.2565

22. Wang D, Hu B, Hu C, Zhu F, Liu X, Zhang J, et al. Clinical characteristics of 138 hospitalized patients with 2019 novel coronavirus-infected pneumonia in Wuhan, China. Jama 2020; 323:1061-9.

23. Yang $X, Y u Y, X u$ J, Shu $H$, Xia J, Liu H, et al. Clinical course and outcomes of critically ill patients with SARS-CoV-2 pneumonia in Wuhan, China: a single-centered, retrospective, observational study. Lancet Respir Med. 2020 May;8(5):475-481. http://dx.doi.org/10.1016/S2213-2600(20)30079-5

24. McCullough PA, Eidt J, Rangaswami J, Lerma E, Tumlin J, Wheelan K, et al. Urgent need for individual mobile phone and institutional reporting of at home, hospitalized, and intensive care unit cases of SARS-CoV-2 (COVID-19) infection. Rev Cardiovasc Med. 2020 Mar 30;21(1):1-7. http://dx.doi. org/10.31083/j.rcm.2020.01.42

25. Centers of Disease Control and Prevention. People Who Are at Higher Risk for Severe IIIness. 2020 [cited 2020 May 6]. Available from: <https://www.cdc.gov/coronavirus/2019ncov/need-extra-precautions/people-at-higher-risk.html>.

26. Bulut C, Kato Y. Epidemiology of COVID-19. Turk J Med Sci. 2020 Apr 21;50(SI-1):563-570. http://dx.doi.org/10.3906/ sag-2004-172

27. Lee PI, Hu YL, Chen PY, Huang YC, Hsueh PR. Are children less susceptible to COVID-19? J Microbiol Immunol Infect. 2020 Jun;53(3):371-372. http://dx.doi.org/10.1016/j.jmii.2020.02. 011

28. Dong $Y, M o X, H u$ Y, Qi X, Jiang F, Jiang Z, et al. Epidemiology of COVID-19 Among Children in China. Pediatrics. 2020 Jun;145(6):e20200702. http://dx.doi.org/10.1542/peds.2020-0 702

29. World Health Organization. Coronavirus disease 2019 (COVD-19). Situation report-40, Geneva, Switzerland: WHO; 2020. https://www.who.int/docs/default-source/ coronaviruse/situationreports/20200229-sitrep-40-covid-19. pdf?sfvrsn=849d0665_2 (acessado em 06/Mai/2020).

30. Lai CC, Shih TP, Ko WC, Tang HJ, Hsueh PR. Severe acute respiratory syndrome coronavirus 2 (SARS-CoV-2) and coronavirus disease-2019 (COVID-19): The epidemic and the challenges. Int J Antimicrob Agents. 2020 Mar;55(3):105924. http://dx.doi.org/10.1016/j.ijantimicag.2020.105924

31. World Health Organization. Coronavirus disease (COVID-19). 2020 [cited 2020 May 6]. Available from: <https://covid19. who.int/>.

32. Ran L, Chen X, Wang Y, Wu W, Zhang L, Tan X. Risk Factors of Healthcare Workers with Corona Virus Disease 2019: A
Retrospective Cohort Study in a Designated Hospital of Wuhan in China. Clin Infect Dis. 2020 Mar 17:ciaa287. http:// dx.doi.org/10.1093/cid/ciaa287

33. World Health Organization. Coronavirus disease (COVID-19) outbreak: rights, roles and responsibilities of health workers, including key considerations for occupational safety and health. 2020 [cited 2020 May 6]. Available from: <https:// www.who.int/publications-detail/coronavirus-disease-(covid19)-outbreak-rights-roles-and-responsibilities-of-healthworkers-including-key-considerations-for-occupationalsafety-and-health>.

34. To KK, Tsang OT, Yip CC, Chan KH, Wu TC, Chan JM, et al. Consistent Detection of 2019 Novel Coronavirus in Saliva. Clin Infect Dis. 2020 Jul 28;71(15):841-843. http://dx.doi. org/10.1093/cid/ciaa149

35. Wei J, Li Y. Airborne spread of infectious agents in the indoor environment. Am J Infect Control. 2016 Sep 2;44(9 Suppl):S102-8. http://dx.doi.org/10.1016/j.ajic.2016.06.003

36. Peng $X, X u$ X, Li Y, Cheng L, Zhou X, Ren B. Transmission routes of 2019-nCoV and controls in dental practice. Int J Oral Sci. 2020 Mar 3;12(1):9. http://dx.doi.org/10.1038/s41368020-0075-9

37. Van Doremalen N, Bushmaker T, Morris DH, Holbrook MG, Gamble A, Williamson BN et al. Aerosol and Surface Stability of SARS-CoV-2 as Compared with SARS-CoV-1. N Engl J Med. 2020 Apr 16;382(16):1564-1567. http://dx.doi.org/10.1056/ NEJMc2004973

38. American Dental Association. ADA Interim Guidance for Minimizing Risk of COVID-19 Transmission. 2020. [cited 2020 May 6]. Available from: <https://www.ada.org/ /media/CPS/ Files/COVID/ADA_COVID_Int_Guidance_Treat_Pts.pdf?utm_ source=adaorg\&utm_medium $=$ covi $\% 20$ d-resourcesIp\&utm_content=cv-pm-ebd-interim-response\&utm_ campaign=covid $-19>$.

39. Centers of Disease Control and Prevention. Interim Infection Prevention and Control Guidance for Dental Settings During the COVID-19. 2020 [cited 2020 May 6]. Available from: <https://www.cdc.gov/coronavirus/2019-ncov/hcp/dentalsettings.html>.

40. Conselho Federal de Odontologia. Manual de boas práticas em biossegurança para ambientes odontológicos. 2020 [Acesso em 6 maio 2020]. Disponível em: <http://website.cfo.org. br/covid19-manual-de-boas-praticas-em-biosseguranca-paraambientes-odontologicos-e-lancado-com-apoio-institucionaldo-cfo/s.

41. Agência Nacional de Vigilância Sanitária. Nota técnica GVIMS/ GGTES/ANVISA $N^{\circ}$ 04/2020. Orientações para serviços de saúde: medidas de prevenção e controle que devem ser adotadas durante a assistência aos casos suspeitos ou confirmados de infecção pelo novo coronavírus. 2020 Acesso em 8 maio 2020]. Disponível em: <http://portal.anvisa.gov. br/documents/33852/271858/Nota+T\%C3\%A9cnica+n+042020+GVIMS-GGTES-ANVISA/ab598660-3de4-4f14-8e6fb9341c196b28>.

42. Centers of Disease Control and Prevention. Guidelines for Infection Control in Dental Health-Care Settings, 2003 [cited 
2020 May 6]. Available from: <https://www.cdc.gov/mmwr/ preview/mmwrhtml/rr5217a1.htm>.

43. Centers of Disease Control and Prevention. Summary of Infection Prevention Practices in Dental Settings: Basic Expectations for Safe Care. 2016 Acesso em 6 maio 2020]. Disponível em: <https://www.cdc.gov/oralhealth/ infectioncontrol/summary-infection-prevention-practices/ index.html>.

44. World Health Organization. Infection prevention and control of epidemic-and pandemic-prone acute respiratory infections in health care. 2014 Acesso em 6 maio 2020]. Disponível em: <https://apps.who.int/iris/ bitstream/handle/10665/112656/9789241507134_eng. pdf? sequence $=1>$.
45. Agência Nacional de Vigilância Sanitária. Manual - Serviços Odontológicos Prevenção e Controle de Riscos. 2006 [Acesso em 8 maio 2020]. Disponível em: <https://bvsms.saude.gov. br/bvs/publicacoes/manual_odonto_servicos.pdf >.

46. Associação Brasileira de Odontologia. Biossegurança e Segurança do Paciente. 2018 [Acesso em 8 maio 2020]. Disponível em: <https://www.abo.org.br/uploads/ files/2018/06/manual-de-biosseguranca-revisado.pdf>.

47. Day M. Covid-19: ibuprofen should not be used for managing symptoms, say doctors and scientists. BMJ. 2020 Mar 17;368:m1086. http://dx.doi.org/10.1136/bmj.m1086

Received on: 18/5/2020 Approved on: 28/7/2020 